\title{
Genetic variability in maize and teosinte populations estimated by microsatellites markers
}

\author{
Variabilidade genética em populações de milho e teosinto estimada por marcadores microssatélites
}

\author{
Tatiana de Freitas Terra ${ }^{\mathrm{I}}$ Paula Wiethölter ${ }^{\mathrm{I}}$ Cícero Carlos de Souza AlmeidaII \\ Sérgio Delmar dos Anjos e Silva ${ }^{\mathrm{III}}$ Fernanda Bered ${ }^{\mathrm{IV}}$ Maria Jane Cruz de Melo Sereno ${ }^{\mathrm{V}}$ \\ José Fernandes Barbosa Neto ${ }^{\mathrm{V}}$
}

\begin{abstract}
Wild species are important sources of genetic variability and may be exploited by breeding programs. Crosses between teosinte and maize occur freely and teosinte serves as genetic source of agronomic traits for introduction in maize. The objective of this study was to estimate genetic variability among and within maize and teosinte populations (Zea mays mexicana). Two sweet maize populations (BR400 and BR402), two common maize populations (Suwan and Pampa) and one teosinte population were analyzed using microsatellites markers. Results indicated that $64,5 \%$ of the variation was detected within the populations, suggesting the possibility of obtaining genetic progress by selection within each population. The analysis with 25 microsatellites loci enabled the identification of 92 alleles with a mean of 3.7 alleles per locus. The average Polymorphism Information Content (PIC) was 0.52. The percentage of polymorphic loci varied from $64 \%$ in the BR400 and Pampa populations to $80 \%$ in the teosinte population. The estimated genetic distance confirmed the genomic similarity of maize and teosinte.
\end{abstract}

Key words: Zea mays mays, Zea mays mexicana, genetic diversity, flooding tolerance; molecular markers.

\section{RESUMO}

Espécies silvestres são fontes importantes de variabilidade genética e podem ser exploradas pelos programas de melhoramento. Cruzamentos entre teosinto e milho ocorrem naturalmente, e o teosinto pode ser utilizado como fonte de caracteres agronômicos para introdução em milho. $O$ objetivo deste estudo foi estimar a variabilidade genética entre e dentro de populações de milho e teosinto (Zea mays mexicana). Duas populações de milho doce (BR400 e BR402), duas de milho comum (Suwan e Pampa) e uma de teosinto foram analisadas utilizando-se marcadores microssatélites. Os resultados indicaram que $64,5 \%$ da variação foi detectada dentro das populações, sugerindo a possibilidade de obtenção de progresso genético através da seleção dentro de cada população. A análise de 25 locos microssatélites permitiu identificar 92 alelos, com uma média de 3,7 alelos por loco. $O$ percentual de locos polimórficos variou de $64 \%$ nas populações BR400 e Pampa a $80 \%$ na população de teosinto. A distância genética estimada confirmou a similaridade genética entre milho e teosinto.

Palavras-chave: Zea mays mays, Zea mays mexicana, diversidade genética, tolerância ao encharcamento, marcadores moleculares.

\section{INTRODUCTION}

Cultivated maize (Zea mays mays) is derived from teosinte (Zea mays parviglumys) and their morphological differences resulted from human

'Programa de Pós-graduação em Fitotecnia, Faculdade de Agronomia, Universidade Federal do Rio Grande do Sul (UFRGS), Porto Alegre, RS, Brasil.

"Universidade Federal de Alagoas (UFAL), Arapiraca, AL, Brasil.

"'Empresa Brasileira de Pesquisa Agropecuária (EMBRAPA), Centro de Pesquisa de Agricultura de Clima Temperado, Pelotas, RS, Brasil.

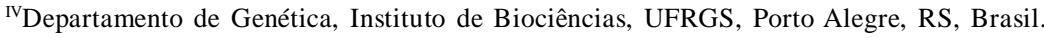

${ }^{\vee}$ Departamento de Plantas de Lavoura, Faculdade de Agronomia, UFRGS, Porto Alegre, RS, Brasil.

VI*Departamento de Plantas de Lavoura, Faculdade de Agronomia, UFRGS, 91501-970, Porto Alegre, RS, Brasil. E-mail: jfbn@ufrgs.br. Autor para correspondência. 
selection in the process of domestication (WANG et al., 1999; MATSUOKA et al., 2002; DOEBLEY, 2004; VIGOUROUX et al., 2005). Despite being one of the cultivated species with greater genetic diversity, molecular analysis of the maize genome suggest that a single domestication event reduced diversity when compared with teosinte (VIGOUROUX et al., 2002; WARBURTON et al., 2008). Most maize commercial varieties in the world has limited genetic diversity, whereas today the germplasm base in maize breeding programs is relatively narrow (TARTER et al., 2004; LE CLERE et al., 2005). In general, wild species, such as teosinte, may contain useful allelic variation for genetic breeding.

Crosses between teosinte and maize occur freely and information about the teosinte diversity might serve as genetic source of agronomic traits for introduction in maize. PASZTOR \& BORSOS (1990) and SRINIVASAN \& BREWBAKER, (1999) reported the existence of genetic variability for different important agronomic traits in teosinte, like genes for diseases and insects resistance.

The contribution of wild species to breeding cultivated species is common and TANKSLEY \& NELSON (1996) proposed a method involving QTL mapping and integration of wild species for tomato. Later studies proved the efficiency of the method of incorporating different traits of agronomic interest (BERNACCHI et al., 1998; WIETHÖLTER et al., 2008). The characterization of adapted and wild populations is a fundamental aspect to increase the introduction of favorable genes in breeding programs (LABORDA et al., 2005). VIGOUROUX et al. (2002) used SSR to identify genes of agronomic importance in maize under the influence of selection in the process of domestication. LÜBBERSTEDT et al. (1998) studied microsatellite variation in maize and suggested their use in detecting genetic variability in associated genotypes, which can be applied to maize and teosinte. The main objective of the present study was to estimate genetic variability among and within maize and teosinte Brazilian populations for breeding purposes using 25 microsatellites loci.

\section{MATERIALS AND METHODS}

Two sweet maize populations BR400 and BR402 (Hawaiian super sweet series and Hawaiian sweet series, respectively), two common maize populations Suwan and Pampa (Dent landraces mixture) and one teosinte population (Zea mays mexicana, landrace selection) were analyzed. All populations were provided by EMBRAPA. Each population was represented by 19 plants, totaling 95 samples. The DNA was extracted individually by the CTAB method (MURRAY \& THOMPSON, 1980) and quantified by spectrophotometer (GENESYS ${ }^{\mathrm{TM}}$ 2).

Twenty-five microsatellite loci were selected from the maize genome database (www.maizegdb.org) (Table 1). The reactions were prepared for a $20 \mu \mathrm{l}$ volume, containing 60ng genomic DNA; 10x buffer Gibco BRL (Tris-HCl $20 \mathrm{mM}, \mathrm{KCl} 50 \mathrm{mM}$ ), $1.5 \mathrm{mM} \mathrm{MgCl} ; 0.2 \mathrm{mM}$ dNTPmix; 1U TaqDNA Polymerase and $0,3 \mathrm{mM}$ of each primer. The amplifications were carried out in a thermocycler (model PTC-100 ${ }^{\mathrm{m}}$, MJ Research Inc.). A touchdown type program was used to amplify the genomic DNA, that consisted of 18 cycles of $94^{\circ} \mathrm{C}$ for one minute followed by a decrease of $1^{\circ} \mathrm{C}$ every two cycles $\left(64^{\circ} \mathrm{C}\right.$ to $\left.55^{\circ} \mathrm{C}\right)$ and one cycle at $72^{\circ} \mathrm{C}$ for one minute. There were a further 20 cycles at $94^{\circ} \mathrm{C}$ for 1 minute, $55^{\circ} \mathrm{C}$ for 1 minute and $72^{\circ} \mathrm{C}$ cycles also for 1 minute.

The amplification products were separated in $3 \%$ agarose gel and developed in ethidium bromide. All 95 samples were placed in the same agarose gel. The bands visualized in agarose gels were evaluated using a binary matrix for presence or absence. Scoring was done manually to determine the molecular weight of the respective DNA amplified fragments. Alleles were named based on the positions of the bands relative to the DNA marker ladder (100bp). The number of alleles per locus and allele frequency in the populations was analyzed. The polymorphism information content (PIC), also named expected heterozygosity (NEI, 1987), was estimated by the expression PIC $=1-\Sigma p u^{2}$ (BERED et al., 2005; LABORDA et al., 2005), where $p u$ is the frequency of allele $u$. The genetic distance among the populations was estimated by the Nei coefficient (1978) and the clustering analysis was performed by the Unweighted Pair-Group Method Using an Arithmetic Average method. Procedure SAHN of the NTSYS (ROHLF, 2000) was used to obtain the dendogram. The PIC calculation and the distance matrix were performed using Microsoft Excel and TFPGA software (MILLER, 1997), respectively. Analysis of molecular variance AMOVA (EXCOFFIER et al., 1992) was used to analyze the genetic diversity among and within each population.

\section{RESULTS AND DISCUSSION}

The analysis of individuals belonging to five different populations using 25 microsatellite loci enabled the identification of 92 alleles with a mean of 3.7 alleles per locus (Table 1). LU \& BERNARDO (2001), analyzing maize commercial lines with 83SSR markers, 
Table 1 - Microsatellite primers, number and size of the alleles per locus and Polymorphism Information Content (PIC).

\begin{tabular}{|c|c|c|c|c|c|c|}
\hline Primer & Motif & Chromosome & Gene name & № of alleles & Size (bp) & PIC \\
\hline umc1064 & $(\mathrm{CT})_{8}$ & 1 & ferrodoxin 3 & 3 & $140-165$ & 0.64 \\
\hline umc1331 & $(\mathrm{GGT})_{10}$ & 1 & - & 3 & 149 & 0.41 \\
\hline umc1363 & $(\mathrm{ACG})_{4}$ & 1 & - & 5 & 111 & 0.72 \\
\hline umc1185 & $(\mathrm{GC})_{8}$ & 2 & oleosin 1 & 3 & $115-140$ & 0.50 \\
\hline umc1622 & $(\mathrm{AAG})_{5}$ & 2 & Cytokinin response regulator 1 & 3 & $40-90$ & 0.32 \\
\hline umc1696 & $(\mathrm{GA})_{8}$ & 2 & - & 6 & 160 & 0.81 \\
\hline phi029 & $\mathrm{AG} / \mathrm{AGCG}^{* * *}$ & 3 & triose phosphate isomerase 4 & 3 & $144-165$ & 0.55 \\
\hline umc1683 & $(\mathrm{CT})_{6}$ & 3 & - & 5 & 81 & 0.38 \\
\hline umc1594 & $(\mathrm{TA})_{10}$ & 3 & - & 9 & 128 & 0.80 \\
\hline phi021 & $\mathrm{AG}$ & 4 & alcohol dehydrogenase 2 & 6 & $85-114$ & 0.75 \\
\hline nc004 & AG & 4 & alcohol dehydrogenase 2 & 4 & $150-180$ & 0.68 \\
\hline umc1294 & $(\mathrm{GAG})_{4}$ & 4 & - & 3 & 141 & 0.56 \\
\hline umc1620 & $(\mathrm{TTC})_{4}$ & 4 & - & 2 & 143 & 0.50 \\
\hline phi085 & AACGC & 5 & glutamine synthetase 4 & 1 & $73-107$ & 0.00 \\
\hline umc1097 & $(\mathrm{CA})_{8}$ & 5 & - & 5 & - & 0.69 \\
\hline umc1225 & $(\mathrm{AG})_{6}$ & 5 & - & 4 & 150 & 0.62 \\
\hline $\mathrm{nc012}$ & CT & 6 & pyruvate, orthophosphate dikinase 1 & 3 & $110-130$ & 0.39 \\
\hline umc 1023 & $(\mathrm{AT})_{11}$ & 6 & ferrodoxin 2 & 3 & - & 0.58 \\
\hline umc 1545 & $(\mathrm{AAGA})_{4}$ & 7 & heat shock protein 3 & 3 & $48-80$ & 0.42 \\
\hline umc1433 & $(\mathrm{AG})_{6}$ & 7 & - & 3 & 92 & 0.55 \\
\hline umc1202 & $(\mathrm{GGC})_{7}$ & 8 & ribosome-inactivating protein 1 & 3 & $140-161$ & 0.43 \\
\hline umc1034 & $(\mathrm{GA})_{12}$ & 8 & - & 4 & - & 0.74 \\
\hline phi032 & AAAG & 9 & sucrose synthetase 1 & 2 & $215-244$ & 0.29 \\
\hline phi071 & GGA & 10 & heat shock protein & 1 & - & 0.00 \\
\hline umc1648 & $(\mathrm{TC})_{8}$ & 10 & - & 5 & 137 & 0.66 \\
\hline Mean & - & - & - & 3.7 & - & 0.52 \\
\hline
\end{tabular}

detected 4.9 alleles per SSR loci and SENIOR et al. (1998) found 5.2 alleles per loci in 70SSR loci. In addition, PEJIC et al. (1998) detected a mean of 6.8 alleles in 27SSR loci and PATTO et al. (2004), using 15SSR loci, detected 5.3 alleles when analyzing maize genotypes. However WIETHÖLTER et al. (2008) detected an average of 2.7 alleles per locus in 23SSR loci, in a study of genetic variability in maize landraces.

The allele sizes detected ranged from 40 to 244bp (Table 1), which is in agreement with the results presented by MATSOUKA et al. (2002) and SENIOR et al. (1998). As observable by WIETHÖLTER et al. (2008), the lowest number of alleles detected in this study may reflect the use of agarose gels, which have lower resolution and may underestimate the number of alleles detected (TARTER et al., 2004). However, although it is know that SSR analysis in agarose gels may result in underestimation of the variability, it is indicated especially because it is a cheap and a quick technique (SENIOR et al., 1998). Several studies have shown that the pattern of clustering observed among the genotypes tested by this method is consistent with the pedigree information (MENKIR et al., 2004;
LABORDA et al., 2005; LEGESSEet al., 2007), confirming the efficiency of this methodology. According to WIETHÖLTER et al. (2008), a factor that might be related is the origin of the varieties studied. The close origin and the short period for differentiation can led to lower levels of allele variation. Furthermore, the SSR primers used might have presented little polymorphism in the group of genotypes analyzed.

One locus (umcl594) presented nine different alleles in the five populations assessed and two loci (phi071 and phi085) were monomorphic. VIGOUROUX et al. (2005) indicated that maize SSRs presenting dinucleotide motif, in general, have more alleles than other SSR motifs. Overall, this analysis contains large number of SSR primers dinucleotide, such as umc1594.

The polymorphism information content (PIC) indicates the discriminatory power of a marker and varied from 0.29 in primer phi032, associated with sucrose synthesis, to 0.81 in primer umc1696, excluding the monomorphic primers (Table 1). The mean PIC was 0.52 , which was similar to that reported by AMORIM et al. (2003) and BERED et al (2005) in the analysis of 
genetic diversity in sweet maize, as well as maize commercial lines (0.56) used by PATTO et al. (2004). On the other hand, MATSUOKA et al. (2002) found an average PIC of 0.62 (varying from 0.18 to 0.89 ) and 0.73 (varying from 0.22 to 0.91 ) in microsatellite analysis in maize lines and joint analysis of teosinte and maize, respectively. The PIC is the degree of polymorphism detected by a determined pair of primers and is directly related to the variability of the chromosome region and with the genotypes studied. Thus a reduced PIC may indicate that the region is conserved in the group of genotypes studied. Considering only the microsatellites located in regions with known function in biochemical routes of basic physiological metabolisms, the average PIC was 0.43 , with a variation of 0.00 (glutamine synthetase and heat shock protein) to 0.75 (alcohol dehydrogenase 2). MATSUOKA et al. (2002) analyzed the variability of primers phi029 (triose phosphate isomerase 4) and phi032 (sucrose synthetase 1) and detected a PIC of 0.73 for both when 60 open-pollinated populations of teosinte and maize and 101 inbred lines were analyzed, representing the three largest sources of maize germplasm in the world. The analysis of a smaller number of individuals and only germplasm adapted to southern Brazil may have contributed to the estimation of lower PIC values in the present study.

The percentage of polymorphic loci varied from $64 \%$ in the BR400 and Pampa populations to $80 \%$ in the teosinte population (Table 2). Similar results were reported by VIGOUROUX et al. (2005), which found less SSR variation in a group of maize landraces when compared to annual teosinte. The genetic variability estimated by the sum of the squares of AMOVA was larger in the teosinte population and there was no difference when only the 13 microsatellites associated with genes involved in biochemical routes of basic physiological metabolism were considered. A smaller genetic variability was detected in the common and sweet maize populations, and the Pampa population contributed most to this variance. The mean variability of the populations, compared with other studies, was smaller than that reported by AMORIM et al. (2003), and MATSUOKA et al. (2002). This smaller genetic variability found may be explained by the fact that in the present study 13 microsatellites used were associated with genes involved in biochemical routes of basic physiological metabolisms, which are naturally more conserved with less variation within the genome of each population. These regions were selected because they are involved in energy production processes in the absence of oxygen, which indicates the possibility of selection for flood tolerance in these populations. This trait is very important in southern Brazil, representing an alternative for exploitation of fertile areas with flooding problems (VITORINO et al. 2001).

The analysis of molecular variance indicated that $64.5 \%$ the variation was detected within the populations (Table 3). Considering only the microsatellites located in regions with known function, AMOVA showed that most of the variation observed

Table 2 - Percentage of polymorphism and number of alleles per locus in BR400, BR402, Pampa, Suwan and teosinte populations.

\begin{tabular}{|c|c|c|c|}
\hline Population & Polymorphic loci (\%) & № of alleles/polymorphic loci & Sum of squares \\
\hline BR400 & 64 & 2.3 & 3.61 \\
\hline BR402 & 72 & 2.9 & 3.70 \\
\hline Pampa & 64 & 2.5 & 3.92 \\
\hline Suwan & 76 & 2.7 & 3.29 \\
\hline Teosinte & 80 & 2.9 & 4.44 \\
\hline BR400 & 54 & 2.1 & 3.14 \\
\hline BR402 & 54 & 2.6 & 2.80 \\
\hline Pampa & 69 & 2.3 & 3.49 \\
\hline Suwan & 69 & 2.7 & 2.69 \\
\hline Teosinte & 69 & 2.7 & 4.30 \\
\hline
\end{tabular}


Table 3 - Analysis of molecular variance (AMOVA) of the allele frequencies of 25 microsatellite loci in five maize populations (BR400, BR402, Pampa, Suwan and teosinte).

\begin{tabular}{llccc}
\hline Causes of Variation & $\mathrm{df} \mathrm{f}^{*}$ & MS** & Variance Components & Percentage of Variation (\%) \\
\hline \multirow{2}{*}{ Between populations } & 4 & All 25 microsatellites & 35.5 \\
Within populations & 91 & 2.41 & 0.11 & 64.5 \\
& \multicolumn{1}{c}{13 microsatellites located in regions with known function } \\
Between populations & 4 & 2.35 & 0.11 & 38.6 \\
Within populations & 91 & 0.18 & 0.18 & 61.4 \\
\hline
\end{tabular}

*Degrees of freedom; ** Mean squared deviations.

was located within the populations tested. The mean percentage of heterozygote individuals within the populations was $26 \%$. These values suggested the possibility of obtaining genetic progress by selection within each population.

The genetic distance expressed allelic differences that occur during the evolution and enabled the separation of the populations analyzed as expected (Figure 1). The values of genetic distance ranged of 0.24 (between maize populations Pampa and Suwan) up to 0.78 (between teosinte and Pampa). The genetic distances results indicated the specific genetic diversity of the wild teosinte. Generally, these results confirmed the genomic similarity of maize and teosinte and that the maize populations analyzed in the present study had little variation in allele frequencies, which is in accordance with the values of genetic similarity presented by SENIOR et al. (1998) and BERED et al. (2005) that evaluated elite maize inbreds and sweet corn populations, respectively.

This germplasm should be investigated to detected more traits in its genetic diversity that has potential for use in breeding programs. Thus, it would be possible to introduce the useful genes into commercial genotypes.

\section{ACKNOWLEDGMENTS}

The authors are grateful to the EMBRAPA for providing samples and Brazilian agencies: Conselho Nacional de Desenvolvimento Científico e Tecnológico (CNPq) and Coordenação de Aperfeiçoamento de Pessoal de Nível Superior (CAPES) for financial support of this research.

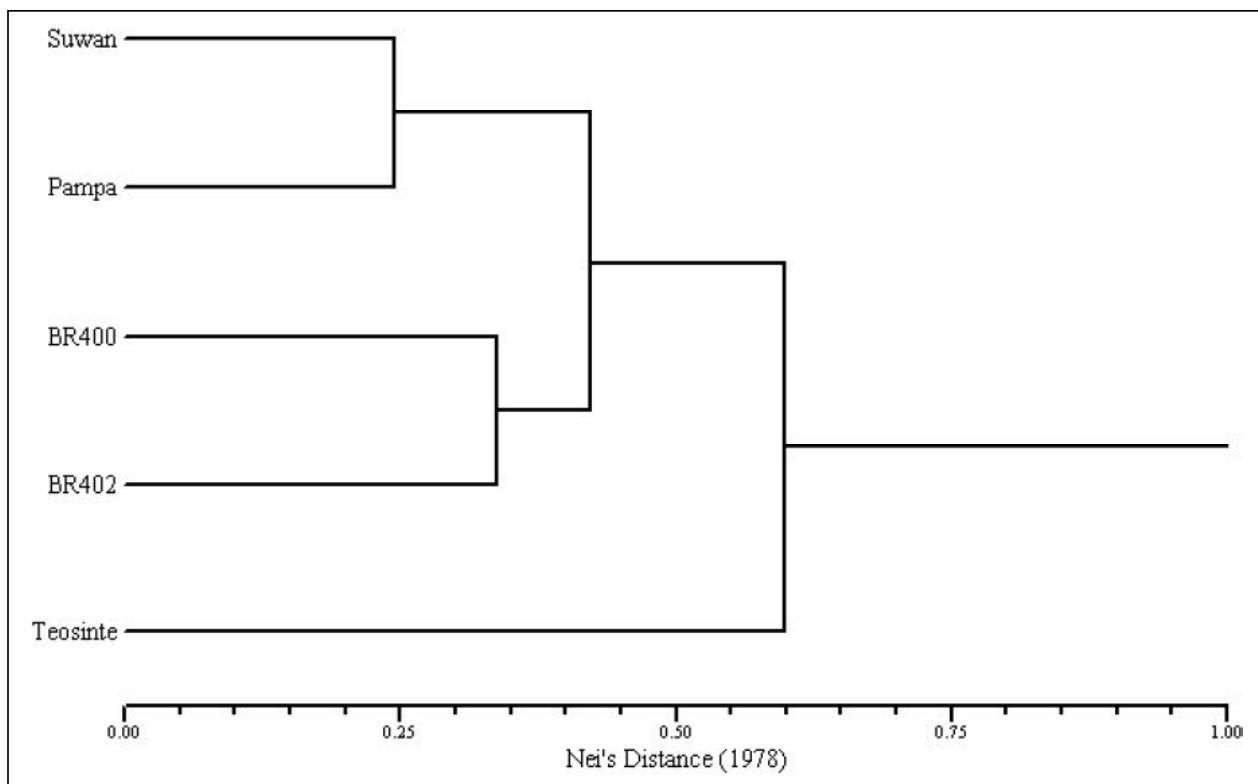

Figure 1 - Clustering obtained by the genetic distance matrix from the data generated by the genetics assessments based on Nei's Distance (1978).

Ciência Rural, v.41, n.2, fev, 2011. 


\section{REFERENCES}

AMORIM, E.P. et al. Genetic variability in sweet corn using molecular markers. Maydica, v.48, p.177-181, 2003. Available from: <http://www.maiscoltura.it/maydica/articles/48_177.pdf>. Accessed: Apr. 13, 2010.

BERED, F. et al. Genetic variation among and within sweet corn populations detected by RAPD and SSR markers. Crop Breeding and Applied Biotechnology, v.5, p.418-425, 2005. Available from: <http://www.sbmp.org.br/cbab/siscbab/uploads/ bd6b8337-51fa-b952.pdf>. Accessed: May 12, 2010.

BERNACCHI, D. et al. Advanced backcross $Q T L$ analysis of tomato. II. Evaluation of near isogenic lines carrying singledonor introgressions for desirable wild $Q T L$-alleles derived from Lycopersicon hirsutum and L. pimpinellifolium. Theoretical and Applied Genetics, v.97, p.170-180, 1998. Available from: <http://www.springerlink.com/content/ghwemj8fcep $167 \mathrm{yc} /$ fulltext.pdf $>$. Accessed: Mar. 10, 2010.

DOEBLEY, J. The genetics of maize evolution. Annual Review of Genetics, v.38, p.37-59, 2004. Available from: <http://www.ndsu.edu/ pubweb/ mcclean/plsc731/homework/papers/doebley\%20$\% 20$ the $\% 20$ genetics $\% 20$ of $\% 20$ maize $\% 20$ evolution.pdf $>$. Accessed: May 12, 2010.

EXCOFFIER, L. et al. Analysis of molecular variance inferred from metric distances among DNA haplotypes: application to human mitochondrial DNA data. Genetics, v.131, p.479491, 1992.

LABORDA, P.R. et al. Tropical maize germplasm: what can we say about its genetic diversity in the light of molecular markers? Theoretical and Applied Genetics, v.111, p.12881299, 2005. Available from: <http://www.springerlink.com/ content/q057008902368n70/fulltext.pdf >. Accessed: May 10, 2010. doi: 10.1007/s00122-005-0055-7.

LE CLERE, V. et al. Assessing temporal changes in genetic diversity of maize varieties using microsatellite markers. Theoretical and Applied Genetics, v.110, p.294-302, 2005. Available from: <http://www.springerlink.com/content/ qypmrj5fvyae7vpd/fulltext.pdf $>$. Accessed: May 12, 2010. doi: 10.1007/s00122-004-1834-2.

LEGESSE, B.W. et al. Genetic diversity of African maize inbred lines revealed by SSR markers. Hereditas, v.144, p.10-17, 2007. Available from: <http://www3.interscience.wiley.com/ cgi-bin/fulltext/117972146/PDFSTART>. Accessed: Feb. 15, 2009 .

LU, H.; BERNARDO, R. Molecular marker diversity among current and historical maize inbreds. Theoretical and Applied Genetics, v.103, p.613-617, 2001. Available from: <http:// www.springerlink.com/content/4 ma81xkf4 10089 qv/ fulltext.pdf>. Accessed: Feb. 11, 2010.

LÜBBERSTEDT, T. et al. Application of microsatellites from maize to teosinte and other relatives of maize. Plant Breeding, v.117, p.447-450, 1998. Available from: <http:// www3.interscience.wiley.com/cgi-bin/fulltext/119118153/ PDFSTART $>$. Accessed: Mar. 20, 2008. doi: 10.1111/j.14390523.1998.tb01971.x.
MATSUOKA, Y. et al. Microsatellites in Zea-variability, patterns of mutations and use for evolutionary studies. Theoretical and Applied Genetics, v.104, p.436-450, 2002. Available from: <http:/ /www.panzea.org/pdf/Matsuoka_etal_2005_TAG_104_436.pdf $>$. Accessed: May 12, 2010.

MENKIR A. et al. Grouping of tropical mid-altitude maize inbred lines on the basis of yield data and molecular markers. Theoretical and Applied Genetics, v.108, p.1582-1590, 2004. Available from: <http://www.springerlink.com/content/ $21 \mathrm{mg} 1 \mathrm{ufc} 5$ adwdef3/fulltext.pdf $>$. Accessed: May 12, 2010. doi: 10.1007/s00122-004-1585-0.

MURRAY, M.; THOMPSON, W.F. Rapid isolation of highmolecular-weight plant DNA. Nucleic Acids Research, v.8, p.4321-4325, 1980 .

NEI, M. Estimation of average heterozygosity and genetic distance from a small number of individuals. Genetics, v.89, p.583-590, 1978. Available from: <http://www.ncbi.nlm.nih.gov/ pmc/articles/PMC1213855/pdf/583.pdf >. Accessed: Sep. 2, 2010.

NEI, M. Molecular evolutionary genetics. New York: Columbia University, 1987. 512p.

PASZTOR, K.; BORSOS, O. Inheritance and chemical composition in inbred maize (Zea mays L.) x teosinte (Zea mays mexicana Schrader/Iltis) hybrids. Novenytermeles, v.39, p.193-213, 1990.

PATTO, M.C.V. et al. Assessing the genetic diversity of Portuguese maize germplasm using microsatellite markers. Euphytica, v.137, p.63-72, 2004. Available from: <http:// www.springerlink.com/content/p0404114040n5741/ fulltext.pdf $>$. Accessed: May 10, 2010.

PEJIC, I. et al. Comparative analysis of genetic similarity among maize inbred lines detected by RFLPs, RAPDs, SSRs, and AFLPs. Theoretical and Applied Genetics, v.97, p.1248-1255, 1998. Available from: <http:// www.springerlink.com/content/eb19hwbc0qq9vrq5/fulltext.pdf>. Accessed: May 5, 2004. doi: 10.1007/s001220051017.

ROHLF, F.J. Numerical taxonomy and multivariate analysis system. New York: Exeter Software, 2000. 38p.

SENIOR, M.L. et al. Utility of SSR for determining genetic similarities and relationships in maize using an agarose gel system. Crop Science, v.38, p.1088-1098, 1998.

SRINIVASAN, G.; BREWBAKER, J.L. Genetic analysis of hybrids between maize and perennial teosinte. II: Ear traits. Maydica, v.44, p.371-384, 1999.

TANKSLEY, S.D.; NELSON, J.C. Advanced backcross $Q T L$ analysis: a method for the simultaneous discovery and transfer of valuable $Q T L s$ from unadapted germplasm into elite breeding lines. Theoretical and Applied Genetics, v.92, p.191-203, 1996. Available from: <http://www.springerlink.com/content/ 15205172750w6813/>. Accessed: May 12, 2010.

TARTER, J.A. et al. Recovery of exotic alleles in semiexotic maize inbreds derived from crosses between Latin American accessions and a temperate line. Theoretical and Applied Genetics, v.109, p.609-617, 2004. Available from: <http:// www.springerlink.com/content/le7cddfar73ebhqc/fulltext.pdf $>$. Accessed: May 10, 2009. doi: 10.1007/s00122-004-1660-6. 
VIGOUROUX, Y. et al. Identifying genes of agronomic importance in maize by screening microsatellites for evidence of selection during domestication. Proceedings of the National Academy of Sciences of The United States of America, v.99, p.9650-9655, 2002. Available from: <http:// www.pnas.org/content/99/15/9650.full.pdf + html $>$. Accessed: Feb. 17, 2010.

VIGOUROUX, Y. et al. An analysis of genetic diversity across the maize genome using microsatellites. Genetics, v.169, p.1617-1630, 2005. Available from: <http://www.genetics.org/ cgi/reprint/169/3/1617>. Accessed: May 12, 2010.

VITORINO, P.G. et al. Flooding tolerance and cell wall alterations in maize mesocotyl during hypoxia. Pesquisa Agropecuária Brasileira, v.36, p.1027-1035, 2001.
Available from: <http://www.scielo.br/pdf/pab/v36n8/ 6460.pdf $>$. Accessed: May 11, 2010.

WANG, R. et al. The limits of selection during maize domestication. Nature, v.398, p.236-239, 1999. Available from: <http://www.nature.com/nature/journal/v398/n6724/pdf/ 398236a0.pdf>. Accessed: Mar. 9, 2004.

WARBURTON, et al. Genetic diversity in CIMMYT nontemperate maize germplasm: landraces open pollinated varieties, and inbred lines. Crop Science, v.48, p.617-624, 2008. Available from: <http://crop.scijournals.org/cgi/reprint/ 48/2/617>. Accessed: Oct. 8, 2008

WIETHÖLTER, P. et al. Genetic variability in corn landraces from Southern Brazil. Maydica, v.53, p.151-159, 2008. Available from: <http://www.maiscoltura.it/maydica/articles/ 53_151.pdf>. Accessed: May 12, 2010. 